\title{
In vitro mass propagation and greenhouse establishment of Withania somnifera (L.) Dunal (Solanaceae) and comparison of growth and chemical compounds of tissue cultured and seed raised plants
}

\author{
M.A.N. De Silva ${ }^{1}$ and W.T.P.S.K. Senarath ${ }^{2 *}$ \\ ${ }^{l}$ Botany Division, Bandaranaike Memorial Ayurvedic Research Institute, Nawinna, Maharagama. \\ ${ }^{2}$ Department of Botany, Faculty of Applied Science, University of Sri Jayewardenepura, Gangodawila, Nugegoda.
}

Revised: 22 June 2009; Accepted: 25 September 2009

\begin{abstract}
Withania somnifera (L.) Dunal (Solanaceae) is normally propagated by seeds. The percentage germination is low, due to the presence of certain inhibitory compounds in the fruit. Among the local and Indian cultivars, the Indian cultivar is preferred by the pharmaceutical industry due to the starchy nature of roots. The local cultivar is listed as a threatened plant. In the present study, W. somnifera was successfully mass propagated in vitro, acclimatized and compared with seed raised plants.
\end{abstract}

The best callus production was observed in Murashige and Skoog (MS) medium supplemented with $1.0 \mu \mathrm{M}$ kinetin (Kin), $4.5 \mu \mathrm{M}$ benzyl amino purine (BAP), and $1.5 \mu \mathrm{M}$ naphthelene acetic acid (NAA) within a 14 day dark period. Shoot initiation was observed in calli produced from shoot tips and nodal segments cultured in the above medium but not from the calli produced from leaf pieces. The highest shoot multiplication was observed in calli from nodal segments cultured in the presence of $9.0 \mu \mathrm{M}$ BAP and $1.0 \mu \mathrm{M}$ indole-3-actic acid (IAA) (11.30 \pm 1.60$)$. Growth regulator free MS medium was the best medium for rooting. In vitro produced plants were acclimatized successfully $(80 \%)$ in a potting mixture of river sand: top soil: compost $(2: 1: 1)$. The rate of photosynthesis was higher in tissue cultured plants at three months $(4.86 \pm 0.40$ and $5.67 \pm 0.31$ for morning and noon respectively) and six months (6.20 \pm 0.52 and $6.67 \pm 0.33$ for morning and noon respectively), while stomatal resistance showed the opposite of that. TLC fingerprints indicated that there was no significant difference in chemical identities (steroids) present in tissue cultured and seed raised plants.

Keywords: In vitro propagation, photosynthesis, stomatal resistance, Withania somnifera.

\section{INTRODUCTION}

Withania somnifera (L.) Dunal is a valuable medicinal plant which belongs to the family Solanaceae. W. somnifera is normally propagated by seeds. The wall of the fruit contains a chemical which prevent seed germination. Percentage of seed germination decreases drastically with time. There are two cultivars of $W$. somnifera present in Sri Lanka. One is the local cultivar and the other one is an Indian cultivar. The most important part used in medicine is the tuber or root. The Indian cultivar is preferred by drug manufacturers because of the starchy nature of its roots as opposed to the local cultivar of which the roots are fibrous. A protocol developed for micropropagation of the Indian cultivar through tissue culture could possibly be used for both cultivars as a tool for clonal propagation and conservation. The objective of this study was to develop a successful protocol for in vitro mass propagation of $W$. somnifera, acclimatize the in vitro propagated plants and compare them with seed raised plants with regard to growth, physiology and chemical availability.

\section{METHODS AND MATERIALS}

Four-month-old plants of the Indian cultivar were selected as mother plants. Explants were surface sterilized in $10 \%$ Clorox $^{\mathrm{TM}}$ (Sodium hypochlorite) for 10 min and in $70 \%$ alcohol for $2 \mathrm{~min}$, each followed by two successive rinses in sterile distilled water. The Murashige and Skoog (MS) medium was used as the basal medium. Culture media were prepared by adding $30.0 \mathrm{~g} / \mathrm{L}$ sucrose and $8.0 \mathrm{~g} / \mathrm{L}$ agar and the $\mathrm{pH}$ was adjusted to 5.6 before

\footnotetext{
*Corresponding author (senerath@yahoo.co.uk)
} 
being autoclaved. Cultures were maintained at $25 \pm 1{ }^{\circ} \mathrm{C}$ under $3000 \mathrm{~lx}$ light intensity for $16 \mathrm{~h}$ except where callus induction is required. Unless otherwise stated there were 20 replicates in each treatment. Completely randomized design (CRD) was used in all experiments. Analysis of variance (ANOVA) was used to identify whether there were any significant differences between different treatments and the least significant difference (LSD) was used as the mean separation technique.

Callus induction from different explants: Leaf pieces $\left(25.0 \mathrm{~mm}^{2}\right)$ from the fully opened third leaf from the apex, nodal segments and shoot tips of $6.0 \mathrm{~mm}$ were used as explants for callus induction. Explants were cultured on MS basal medium supplemented with $1.0 \mu \mathrm{M}$ (Kinetin) and benzyl amino purine (BAP) and naphthalene acetic acid (NAA) in 3 different combinations.

Cultures were incubated at $25 \pm 1{ }^{\circ} \mathrm{C}$ in the dark for a period of $14 \mathrm{~d}$ for callus initiation and transferred to a $16 \mathrm{~h}$ photoperiod and maintained for another $28 \mathrm{~d}$ because preliminary studies indicated that incubation in continuous darkness for more than $14 \mathrm{~d}$ retarded callus growth. The number of days taken for callus initiation, and the diameter, colour and texture of the callus and level of shoot initiation were recorded after 4 wks.

Determination of a suitable growth regulator combination for shoot proliferation and multiplication: Calli were transferred into MS medium supplemented with $1.0 \mu \mathrm{M}$ indole acetic acid (IAA) and different concentrations of BAP $(4.5,9.0$ or 13.0. $\mu \mathrm{M})$ for shoot proliferation. After $60 \mathrm{ds}$ of incubation under a $16 \mathrm{~h}$ photoperiod, shoot length, number of shoots per callus and number of leaves per shoot were measured.

Determination of suitable growth regulator combination for root induction: Once shoots elongated up to about 5 $\mathrm{cm}$ height they were transferred into the root initiation medium. MS medium was used as the basal medium and indole-3-butyric acid (IBA) $(0.0,5.0$ or $10.0 \mu \mathrm{M})$ and IAA $(0.0,6.0$ or $12.0 \mu \mathrm{M})$ were used as growth regulators. Growth regulator free MS medium was used as the control. The rooting percentage, number of roots per shoot and root lengths were measured after $60 \mathrm{ds}$ of incubation.

Determination of the suitable potting mixture for acclimatization and greenhouse establishment: Rooted plants were carefully removed from the culture medium and washed with sterile distilled water to remove all traces of agar. The tissue cultured plants were then dipped in a solution of $1.0 \mathrm{~g} / \mathrm{L}$ Captan $^{\mathrm{TM}}$ for $5 \mathrm{~min}$. Plantlets were first transferred to river sand which was already sterilized in a hot air oven at $162 \pm 1^{\circ} \mathrm{C}$ for $2 \mathrm{~h}$. Sand trays were kept inside a humid chamber. Humidity was controlled and gradually adjusted to that of ambient conditions by replacing the top cover of the chamber which has different sizes of holes.

After 3 wks the acclimatized plants were transferred into 4 different potting mixtures (Topsoil: coir dust:compost (1:1:1:), river sand:coir dust:compost (2:1:1), river sand:topsoil:compost (2:1:1) and river sand:topsoil:coir dust $(2: 1: 1))$ to determine the suitable potting mixture for the growth of in vitro produced plants. Ten plants were used for each treatment. Potted plants were watered regularly and examined for any attack by pests. Survival percentage was determined after $6 \mathrm{wks}$ of keeping plants in the greenhouse.

Comparison of growth, physiology and chemical nature of tissue cultured plants and seed raised plants: Tissue cultured and seed raised plants of similar size were grown in black polythene bags $(30 \mathrm{~cm} \times 15 \mathrm{~cm})$ and maintained in a greenhouse. There were 20 plants of each type. The growth, height of plants, number of leaves and number of branches were observed over a period of 6 months at $2 \mathrm{wk}$ time intervals. Initial measurements were taken at the time of transplanting plants in the polythene bags. Height was measured from the soil surface to the tip of the shoot.

Rate of photosynthesis and stomatal resistance were considered as the physiological parameters. Rate of photosynthesis of in vitro produced plants and seed raised plants were measured at 3 month and 6 month stages using portable photosynthetic system $\mathrm{Li}-6400$ (LI-COR Inc., USA). Measurements were taken in the morning and afternoon of the day. Stomatal resistance of the leaves was measured in the morning, noon and evening in six month old plants using $\mathrm{AP}^{4}$ cycling Porometer (Delta-T Devices Ltd., UK).

Thin layer chromatography (TLC) was used in order to compare chemical compounds. Samples were air dried (10\% moisture content) and ground. Five grams of each sample were refluxed with $100.0 \mathrm{~mL}$ methanol for $4 \mathrm{~h}$. The extract was filtered and the filtrate was evaporated to dryness under reduced pressure at $50{ }^{\circ} \mathrm{C}$. The dried extracts $(0.15 \mathrm{~g}$ of each) were dissolved in $4.0 \mathrm{~mL}$ methanol. $4.0 \mu \mathrm{L}$ of each solution were spotted separately in the $\mathrm{GF}_{254}$ aluminum pre-quoted TLC plate. Withaferin A was used as the standard. Methanol: dichloromethane: cyclohexane $(0.3: 3.7: 1.0)$ mixture was used as the solvent system. 


\section{RESULTS AND DISCUSSION}

\section{Callus induction from different explants}

Although callus initiation took place in the dark, preliminary studies revealed that continuous darkness (more than 14 days) retarded callus growth. It was observed that after transferring calli into a 16 hour light regime, growth was enhanced and shoot initials were observed in some explants after 20 to 25 days in the same medium. In the presence of $1.0 \mu \mathrm{M}$ Kin, $4.5 \mu \mathrm{M}$ BAP and $1.5 \mu \mathrm{M}$ NAA callus initiation was observed in leaf segments explants after a short period of time $(9.10 \pm 1.10$ days) compared to other tested media. The callus diameter varied significantly among the treatments. The highest callus diameter $(1.90 \pm 0.45)$ was observed in the presence of $1.0 \mu \mathrm{M}$ Kin, $4.5 \mu \mathrm{M}$ BAP and $0.5 \mu \mathrm{M}$ NAA where it took $10.20 \pm 1.10$ days for callus initiation.

There was no significant difference between treatments in the mean number of days taken for callus induction from nodal segment explants. In the presence of $1.0 \mu \mathrm{M}$ Kin and $0.5 \mu \mathrm{M}$ NAA, callus initiation took place in a shorter period of time compared to other tested media. The highest nodal segment explant callus diameter $(1.96 \pm 0.24)$ was observed in the presence of $1.0 \mu \mathrm{M}$ Kin, $4.5 \mu \mathrm{M}$ BAP and $0.5 \mu \mathrm{M}$ NAA, indicating that MS medium supplemented with $1.0 \mu \mathrm{M}$ Kin, $4.5 \mu \mathrm{M}$ BAP and $0.5 \mu \mathrm{M}$ NAA is the best medium for callus induction from nodal segments as well. However, the colour of the callus was yellowish green while the texture was hard, which was different from the calli obtained from leaf segments which were white and mucilaginous.

When shoot tips were used as explants, MS medium supplemented with $1.0 \mu \mathrm{M}$ Kin, $4.5 \mu \mathrm{M}$ BAP and $1.5 \mu \mathrm{M}$ NAA showed the lowest time taken for callus initiation (10.20 \pm 0.78 days) when compared to the other two tested media (11.20 \pm 0.90 and $11.80 \pm 1.30$ days, respectively) but the difference was not significant. Callus diameter was highest $(1.62 \pm 0.38)$ in the presence of $1.0 \mu \mathrm{M} \mathrm{Kin}$, $4.5 \mu \mathrm{M}$ BAP and $0.5 \mu \mathrm{M}$ NAA, and it was $1.38 \pm 0.26$ and $1.45 \pm 0.25$ for the other two tested media. Therefore, it could be suggested that MS medium supplemented with $1.0 \mu \mathrm{M}$ Kin, $4.5 \mu \mathrm{M}$ BAP and $0.5 \mu \mathrm{M}$ NAA is the more suitable medium for callus and shoot initiation from nodal segments and shoot tips of $W$. somnifera (Table 1).

In past studies calli from root and cotyledonary leaf segments have been obtained in $0.11 \mu \mathrm{M} \mathrm{2,} 4$ - D and $0.01 \mu \mathrm{M}$ Kin. Plant regeneration was successful only from calli obtained from hypocotyl segments in the presence of BAP and 6-(r,r-dimethylallyamino)purine (2-iP). The number of calli resulted from shoot tip explants compared to leaf segment explants was higher in MS medium

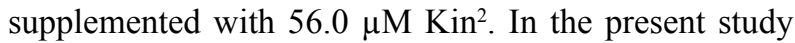
the number of calli obtained from leaf piece explants was higher when compared to that of nodal segments and shoot tips.

Table 1: Callus induction from leaf pieces in different growth regulator combinations after four weeks

\begin{tabular}{lcc}
\hline BAP: NAA $(\mu \mathrm{M})$ & $\begin{array}{c}\text { Mean number of days for } \\
\text { callus initiation }\end{array}$ & $\begin{array}{c}\text { Callus diameter }(\mathrm{cm}) \\
\text { at four weeks }\end{array}$ \\
\hline Leaf pieces & & \\
4.5: 0.5 & $10.20 \pm 1.10$ & $1.90 \pm 0.45^{\mathrm{a}}$ \\
4.5: 1.5 & $9.10 \pm 1.10$ & $1.45 \pm 0.38^{\mathrm{b}}$ \\
0.0: 0.5 & $13.30 \pm 1.10$ & $0.75 \pm 0.17$ \\
LSD 5\% & 8.45 & 1.35 \\
Nodal segments & & \\
4.5: 0.5 & $13.30 \pm 1.10$ & $1.96 \pm 0.24^{\mathrm{a}}$ \\
4.5: 1.5 & $10.70 \pm 1.40$ & $1.49 \pm 0.22^{\mathrm{b}}$ \\
0.0: 0.5 & $7.80 \pm 1.00$ & 0.94 \\
LSD 5\% & 7.40 & $1.62 \pm 0.38^{\mathrm{b}}$ \\
Shoot tips & & $1.38 \pm 0.26^{\mathrm{b}}$ \\
4.5: 0.5 & $11.20 \pm 0.90$ & $1.45 \pm 0.25^{\mathrm{b}}$ \\
$4.5: 1.5$ & $10.20 \pm 0.78$ & 0.47 \\
$0.0: 0.5$ & $11.80 \pm 1.30$ & \\
LSD 5\% & 3.13 & \\
\hline
\end{tabular}

* Measurements are the mean of twenty replicates.

* Means within columns the same letter are not significantly different. 
Table 2: Shoot multiplication in calli obtained from nodal segments and shoot tips of W. somnifera

\begin{tabular}{cccc}
\hline BAP $(\mu \mathrm{M})$ & $\begin{array}{c}\text { Mean number of } \\
\text { leaves }\end{array}$ & $\begin{array}{c}\text { Mean shoot length } \\
(\mathrm{cm})\end{array}$ & $\begin{array}{c}\text { Mean number of shoots } \\
\text { per callus }\end{array}$ \\
\hline Nodal segments & & & \\
4.5 & $5.30 \pm 1.40^{\mathrm{b}}$ & $3.70 \pm 1.00$ & $3.90 \pm 1.10$ \\
9.0 & $11.10 \pm 1.50^{\mathrm{a}}$ & $4.60 \pm 1.10$ & $11.30 \pm 1.60^{\mathrm{e}}$ \\
13.0 & $5.60 \pm 1.70^{\mathrm{b}}$ & $2.50 \pm 0.61$ & $6.40 \pm 1.60^{\mathrm{f}}$ \\
LSD 5\% & 12.66 & 4.12 & 14.60 \\
Shoot tips & & & \\
4.5 & $3.30 \pm 1.00$ & $2.30 \pm 0.50$ & $3.20 \pm 1.40$ \\
9.0 & $9.60 \pm 1.80^{\mathrm{c}}$ & $3.30 \pm 0.80$ & $7.60 \pm 1.60^{\mathrm{g}}$ \\
13.0 & $4.00 \pm 0.90^{\mathrm{d}}$ & $2.20 \pm 0.60$ & $6.20 \pm 1.80^{\mathrm{h}}$ \\
LSD 5\% & 13.39 & 2.40 & 8.70 \\
\hline
\end{tabular}

* Measurements are the mean of twenty replicates.

* Means within columns having the same letter are not significantly different.

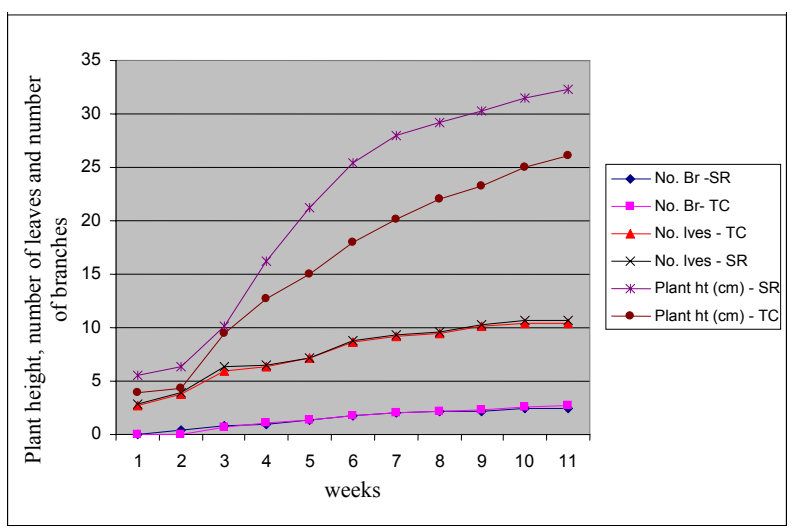

Figure 1: Growth of tissue cultured plants and seed raised plants of W. somnifera

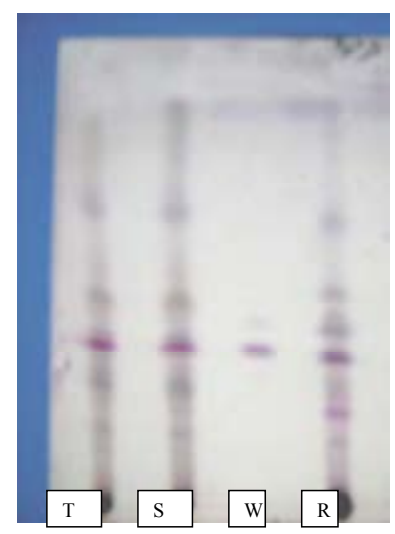

Plate 2: TLC fingerprint of samples T-tissue cultured plants, S- seed raised plants, W-sstandard withaferin A and R- root extract of $W$. somnifera
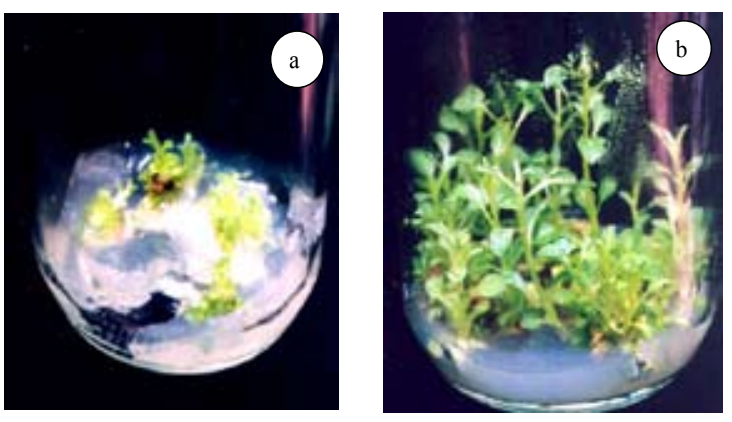

Plate 1: a) Multiple shoot induction and b) elongation of W. somnifera

\section{Determination of a suitable growth regulator combination for shoot proliferation and multiplication}

Calli produced from leaf segments did not produce shoot initials in any of the media tested. In calli induced from nodal segments, shoot multiplication showed a significant difference between treatments for mean number of leaves and mean number of shoots per callus. The highest mean number of leaves, mean shoot length and mean number of shoots per callus were observed in MS medium supplemented with $9.0 \mu \mathrm{M}$ BAP and $1.0 \mu \mathrm{M}$ IAA (Plate1a). Results obtained for callus induction from shoot tip explants were comparable with results obtained from nodal segment explants (Table 2). However, mean number of leaves, mean shoot length and mean number of shoots per callus were lower in calli obtained from shoot tip explants than those from nodal segments. The highest mean number of leaves, mean shoot length and mean number of shoots per callus $(9.60 \pm 1.80,3.30 \pm 0.80$, 
$7.60 \pm 1.60$, respectively) was observed in the medium supplemented with 9.0 $\mu \mathrm{M}$ BAP and 1.0 $\mu \mathrm{M}$ IAA and those values were significantly higher than those obtained from other tested treatments. Therefore, it could be suggested that MS medium supplemented with $9.0 \mu \mathrm{M}$ BAP and 1.0 $\mu \mathrm{M}$ IAA as the better medium for shoot proliferation and multiplication from these calli.

As reported in published work, shoot initials developed from hypocotyle segment calli have been transferred into a medium of MS supplemented with 9.1 $\mu \mathrm{M} 2,4-\mathrm{D}$ and $0.9 \mu \mathrm{M}$ Kin for elongation ${ }^{1}$. Multiple shoots have been induced in MS medium with a growth regulator combination of $2.3 \mu \mathrm{M}$ 2,4-dichlorophenoxyacetic acid (2,4-D), $2.5 \mu \mathrm{M}$ IBA and $4.4 \mu \mathrm{M}$ BAP from shoot tips of in vitro germinated seeds ${ }^{3}$. This is not possible with $W$. somnifera, because seed germination ability decreases with the storage time and at times germination is inhibited by substances present in mucilage around the seeds. Multiple shoots have been produced in low number (2-3) from leaf explants of 3-month-old seedlings ${ }^{4}$ and elongated in MS medium supplemented with $8.8 \mu \mathrm{M}$ BAP and $7.9 \mu \mathrm{M}$ IAA. In the present study, the best medium observed for shoot proliferation is MS medium supplemented with 9.0 $\mu \mathrm{M}$ BAP and $1.0 \mu \mathrm{M}$ IAA, where the BAP level was comparable with previous studies but not the IAA level.

\section{Determination of a suitable growth regulator combination for root induction}

There was a non significant difference in rooting percentage, mean number of roots per shoot and mean root length among the tested concentrations of the growth regulator (Table 3). Rooting percentage, number of roots and root length in MS medium with $12.0 \mu \mathrm{M}$ IBA and growth regulator free MS medium (control) were comparable, and values obtained for control was the highest among the other treatments suggesting that the best medium for root initiation of $W$. somnifera is MS medium without the growth regulator.

In vitro rooting of $W$. somnifera had been achieved in growth regulator free MS medium ${ }^{3}$ and in MS medium supplemented with 0.04 BAP medium ${ }^{4}$. IBA $\left(2.0 \mathrm{mg} \mathrm{L}^{-1}\right)$ alone or a combination with $2.0 \mathrm{mg} \mathrm{L}^{-1} \mathrm{IBA}$ and $2.0 \mathrm{mg} \mathrm{L}^{-1}$ IAA has also been successful in some studies ${ }^{5}$.

\section{Determination of a suitable potting mixture for acclimatization and greenhouse establishment of tissue cultured plants}

Highest survival percentage (80\%) was observed in a potting mixture of river sand: top soil: compost (2:1:1).
Overall survival percentage was low in other tested potting mixtures $(40-50 \%)$. Healthy, well rooted in vitro produced $W$. somnifera plants were transferred into pots containing autoclaved mixture of sand: soil, and acclimatized for 2 weeks under diffused sunlight and $70 \%$ humidity in a greenhouse before being transferred to the field ${ }^{4}$. The establishment of rooted shoots of $W$. somnifera in soil in a greenhouse with $60 \%$ survival $^{3}$ has also been reported. However, the rate of survival in the mixture of river sand: top soil: compost $(2: 1: 1)$ is comparatively higher than those in previous studies.

\section{Comparison of growth, physiology and chemical nature of tissue cultured plants and seed raised plants}

In vitro raised plants are often compared with seed-raised plants in order to identify physiological or morphological disorders, which could appear in the in vitro propagated plants.

The mean height and number of leaves for both types of plants when plotted against time, showed sigmoid patterns. This indicates that the tissue cultured plants have a normal pattern of growth. It was observed that the heights of the seed raised plants are comparably higher than that of tissue cultured plants and the difference occurred after the $6^{\text {th }}$ week. The mean number of leaves was also higher in seed raised plants. In case of branching, both type of plants showed a similar pattern (Figure 1).

In the present study, a higher height increment was also observed with seed raised plants compared to tissue cultured plants. Many researchers in the field of tissue culture have often observed a dwarf appearance of micropropagated plants, which recovered in latter stages of development in the field ${ }^{6,7}$.

The higher height increment of seed raised plants may be due to different ambient conditions during initial stages of seedling growth. Factors that affect the growth of a tissue cultured plant, such as light, space, gas exchange and functional root system are not limited when plants are grown in a greenhouse. The appearance of short stems in tissue cultured plants could also be due to high concentration of cytokinin in the medium ${ }^{6}$.

The leaf number is also higher in seed raised plants compared to those of tissue cultured plants. The difference in height between seed raised and tissue cultured plants is low.

According to the results obtained after three and six months, it was observed that the rate of photosynthesis 
Table 3: Root production of $W$. somnifera in different growth regulator combinations in MS medium supplemented with different growth regulator combinations.

\begin{tabular}{cccc}
\hline $\begin{array}{c}\text { IBA:NAA } \\
(\mu \mathrm{M})\end{array}$ & Rooting percentage & $\begin{array}{c}\text { Mean number of roots } \\
\text { per shoot } \pm \text { SE }\end{array}$ & Mean root length \pm SE \\
\hline $0: 0$ (control) & 60 & $2.71 \pm 2.10$ & $3.10 \pm 3.10$ \\
$5.0: 6.0$ & 50 & $1.70 \pm 1.70$ & $2.30 \pm 2.40$ \\
$10.0: 0.0$ & 60 & $1.90 \pm 1.70$ & $2.20 \pm 2.00$ \\
$0.0: 12.0$ & 60 & $2.10 \pm 1.90$ & $2.90 \pm 2.60$ \\
LSD 5\% & & 0.83 & 1.84 \\
\hline
\end{tabular}

* Measurements are the mean of twenty replicates

Table 4: Rate of photosynthesis of tissue cultured $W$. somnifera plants after three and six month of growth

\begin{tabular}{lcc}
\hline $\begin{array}{l}\text { Rate of photosynthesis } \\
\left(\mu \mathrm{mol} \mathrm{CO} \mathrm{m}^{-2} \mathrm{~s}^{-1}\right)\end{array}$ & Morning & Time \\
\hline Three month & & \\
Tissue cultured plants & $4.86 \pm 0.40^{\mathrm{a}}$ & $5.67 \pm 0.31^{\mathrm{e}}$ \\
Seed raised plants & $3.13 \pm 0.20^{\mathrm{b}}$ & $4.08 \pm 0.30^{\mathrm{f}}$ \\
LSD 5\% & 1.30 & 0.92 \\
Six months & & \\
Tissue cultured plants & $6.20 \pm 0.52^{\mathrm{c}}$ & $6.67 \pm 0.33^{\mathrm{g}}$ \\
Seed raised plants & $4.85 \pm 0.24^{\mathrm{d}}$ & $5.02 \pm 0.30^{\mathrm{h}}$ \\
LSD 5\% & $1.11^{-}$ & 1.23 \\
\hline
\end{tabular}

* Measurements are the mean of six replicates.

* Means within columns having the same letter are not significantly different.

Table 5: Mean stomatal resistance at six months

\begin{tabular}{lccc}
\hline Time & \multicolumn{3}{c}{ Stomatal resistance $\left(\mathrm{s} \mathrm{cm}^{-1}\right)$} \\
& Morning & Noon & Evening \\
\hline Tissue cultured plants & $2.85 \pm 0.40^{\mathrm{b}}$ & $2.01 \pm 0.30^{\mathrm{d}}$ & $2.32 \pm 0.40^{\mathrm{f}}$ \\
Seed raised plants & $5.04 \pm 0.71^{\mathrm{a}}$ & $4.72 \pm 0.40^{\mathrm{c}}$ & $5.64 \pm 0.60^{\mathrm{e}}$ \\
LSD (5\%) & 3.60 & 3.12 & 4.01 \\
\hline
\end{tabular}

* Measurements are the mean of six replicates.

* Means within columns having the same letter are not significantly different.

is significantly higher in tissue cultured plants than seed raised plants. In both types of plants the rate of photosynthesis increased with maturity, with the tissue cultured plants showing a slightly higher rate (Table 4). This shows further establishment of tissue cultured plants under natural environmental conditions. A similar pattern of change in rates of photosynthesis was observed in tissue cultured plants of Munronia pinnata ${ }^{7}$.

The stomatal resistance was significantly lower in tissue cultured plants than those of seed raised plants (Table 5). Both types of plants showed lower stomatal resistance to water loss at noon which may be due to increased ambient temperature. Higher stomatal resistance was observed in six month old seed raised plants.

Many researchers have pointed out the difficulty in controlling water loss of micropropagated plants, which causes severe desiccation upon removal from in vitro cultures ${ }^{9,10}$. This is mainly due to malfunctioning stomata and unresponsive stomata that hinder acclimatization under ex vitro conditions and increase mortality by desiccation ${ }^{11}$. 
Withanolides are the more important bioactive constituents of $W$. somnifera. TLC fingerprints for tissue cultured plants, seed raised plants, standard withaferin $\mathrm{A}$ and root extract of $W$. somnifera proved that the dark purple spots are withaferin A (Plate 2). A detailed study is needed to confirm the chemical compunds present in $W$. somnifera. The results indicate that, in vitro propagation protocol developed in this study could be used in mass clonal propagation of $W$. somnifera since it produced true-to-type plants.

\section{Acknowledgement}

Authors acknowledge the Bandaranaike Memorial Ayurvedic Research Institute, Navinna for providing facilities to conduct this research and the University of Sri Jayewardenepura, Nugegoda for providing financial assistance under research grant $\mathrm{ASP} / 6 / \mathrm{R} / 2006 / 10$. We wish to extend our thanks to Dr. Sirimal Premakumara, Industrial Technology Institute (ITI), Colombo 7 for support in chemical analysis.

\section{References}

1. Githa R., Saroj A. \& Avinash N. (2003). Direct rhizogenesis from in vitro leaves of Withania somnifera (L.) Dunal. Journal of Herbs, Spices and Medicinal Plants 10(3):47-54.

2. Teli N.P., Patil N.M., Pathak H.M., Bhalsing S.R. \& Maheshwari V.L. (1999). Withania somnifera (Ashwaganda); regeneration through meristem culture Journal of Plant Biochemistry and Biotechnology 8(2):109-111.
3. Sen J. \& Sharma A.K. (1991). Micropropagation of Withania somnifera from germinating seeds and shoot tips. Journal of Plant Cell Tissue and Organ Culture 26(2): 71-73.

4. Kulkarni A.A., Thengane S.R. \& Krishnamurthy K.V. (1996). Direct in vitro regeneration of leaf explants of Withania somnifera (L.) Dunal. Journal of Plant Science 119(2): 163-168.

5. Rani G. \& Grover I.S. (1999). In vitro callus induction and regeneration studies in Withania somnifera, Journal of Plant Cell Tissue and Organ Culture 57(1): 23-27.

6. Taji A.M., Williams R.R. \& Sheather W.H. (1996). Comparative anatomy of four rare Australian plants grown in vitro. Botanic Gardens Micropropagation News 2:2. The Royal Botanic Gardens, Kew London, UK.

7. Senerath W.T.P.S.K., Chandrasena K.G.P.H. \& Fernando K.M.E.P. (2007). In vitro mass propagation and greenhouse establishment of Munronia pinnata.(Wall) Theob. (Binkohomba). Journal of the National Science Foundation of Sri Lanka 35(3): 181-190.

8. Hartmann H.T., Kester D.E., Davis F.T. \& Geneve R. L. (1997). Plant Propagation Principles and Practices. Prentice-Hall, inc., Upper Saddle, New Jersey, USA.

9. Conner L.N. \& Conner A.J. (1984). Comparative water loss from leaves of Solanum lacinatum plants cultured in vitro and in vivo. Plant Science Letters 36(1): 241-246.

10. Kelvin L. \& Kleyn J. (1999). Plants from Test Tubes: $A n$ Introduction to Micropropagation, $3^{\text {rd }}$ edition, Timber Press Inc. The maseltine Building, 133, S.W., Second Avenue, Suite 450, Portland, Oregon 97204, USA.

11. Arigita L., Gonzalez A. \& Tomes R.S. (2002). Influence of $\mathrm{CO}_{2}$ and sucrose on photosynthesis and transpiration of Actinida deliciosa explants cultured in vitro. Physiologia Plantarum 115(2): 166-173. 